Krstinić Dalibor*

Zarubica Sara**
UDK: 347.961

Review article

DOI: $10.5937 / \mathrm{ptp} 2101042 \mathrm{~K}$

Received: February 08th 2021

Approved on: March 01st 2021

Pages: $42-54$

\title{
ENFORCEMENT OF PUBLIC NOTARY DOCUMENTS
}

\begin{abstract}
By passing the Law on Public Notaries, the Serbian legislator regulates the issue of the operation of public notaries, their services and activities. The modern public notary practice represents a specific legal activity which contributes to the rise of legal security and the de-congestion of courts. It also leads to a more efficient exercise of the citizens rights and the realization of their civil rights much faster and more easily. A public notary performs a public service autonomously and independently being the party's independent commissioner, and his/her participation in preparing the documents attests to their truthfulness and content. As a result, public notary documents occupy a significant place in contemporary legal transactions. According to the Law on Public Notaries, public notary documents have the property of enforceability, under certain conditions they can provide a basis to directly institute enforcement proceedings before a court of law when the stipulated conditions are satisfied. It is deemed a positive and very useful legal solution, because of which the authors will, in this paper, point out some relevant key points and specific features regarding the enforcement of public notary documents.
\end{abstract}

Key words: public notary, public notary document, notarial act, enforceable document

\footnotetext{
* LLD, Assistant Professor, The Faculty of Law for Commerce and Judiciary in Novi Sad, The University Business Academy in Novi Sad, Serbia, e-mail: krstinicdalibor@yahoo.com

** LLM, PhD candidate of the Faculty of Law, The University of Belgrade, Serbia, e-mail: pocucamsara@gmail.com
} 


\section{Introductory considerations}

Public notaries have a very long tradition, so that they have been present in all historical periods. Their roots can be found as far back as ancient Rome, where documents and other official instruments and writings played a very important part. They were protocols issued by administrations, while everyday, less important activities were recorded in the so-called home books, i.e. records. In the post-classial period, notaries were for the most part slaves, liberated slaves and quite rarely free people, whose task was to write down political speeches. In this period they were not required to have legal education, nor were they controlled by the state. On the other hand, in the third century it already became a rule for notaries to become secretaries of the emperor or the church administration. In this period, notaries were treated as senior officers (Trgovčević Prokić \& Šarkić, 2013).

The notarial institution was for the first time established in our territory with the Law on Public Notaries of the Kingdom of Yugoslavia (The Law on Public notaries of the Kingdom of Yugoslavia'1930). According to provisions of this law, public notaries were appointed by the state, which gave them public authorities. More precisely, public notaries could participate in exercising part of extra-judicial power, also performing some other duties as court commissioners. The public notary activity was connected with the exercise of public authority, which included the drawing up of documents, their certification and attestation. In addition, the legislator also envisaged the possibility for a public notary to prepare private law transactions, which required the notarial act, as well as to certify private documents, issue certificates, deposits, to act on court orders in certain procedures. The public notary activity also enabled the notaries to provide representation in parties' indisputable issues, related to the documents prepared by them. A public notary was able to perform their own duties, the duties of a court commissioner and attorneys' duties (Šarkić, 2004). On the other hand, this Law on Public notaries ceased to apply in 1944, and after World War II the profession of public notaries totally disappeared from our territories, while their duties were assumed by courts and local self-governments. The public notary institution of the Latin type was re-established by the passage of the Law on Public Notaries in 2011 (Živković \& Živković, 2013). Although this Law had been applied throughout the Republic of Serbia territory since 1 September 2012, public notaries started working on 1 September 2014, after numerous alterations and amendments to the law and after the appointment of the first 93 public notaries (Šarkić, Radulović \& Počuča, 2018). 
The introduction of the public notary service leads to a maximum protection of legal relations, interests and statuses of citizens (Gelevski \& Golić, 2008). One of the reasons for instituting the public notary service within the legal system is also a tendency towards a faster and more efficient way of realizing a final exercise of subjective rights and authorities (Jakšić, 2005). In that sense there is a general trend, aimed at avoiding costly and long-lasting court proceedings, to in a faster and simpler manner obtain documents which have the property of enforceability. This purpose is served by public notary documents which, according to the Law on Public Notaries of the Republic of Serbia, have the property of enforceability, and which provide the basis for direct institution of enforcement proceedings. Given the relevant role of public notary documents, in this paper we shall lay particular emphasis on these documents and their enforcement.

\section{Public notary document types}

A public notary document is a document drawn up in writing and certified by a public notary, within their powers, in a legally stipulated form which produces legally stipulated effects (Trgovčević Prokić, 2007). If any one of the specified elements is missing in a document, it may not have the status of a public document, but may have the status of a private document. Private documents on which a public notary has certified signatures, which are in fact classified as notarial certificates and certifications, or the so-called solemnized documents. The aforesaid documents have the significance of condemnatory court and administrative decisions of settlement before courts or administrative authorities (Trgovčević Prokić, 2016). According to provision of article 118 of the Law on General Administrative Procedure, a public document is defined as a document issued in the stipulated form by a government authority within the scope of its powers, which attests to what is certified or established in it (The Law on General Administrative Procedure, 2016). Speaking of the manner of drawing up, or issuing, there are three categories of notarial acts as follows: processed public notary documents, notarial certificates and notarial certifications (Đurđević, 2005). In line with provision of article 6 of the Law on Public Notaries, the legislator stipulates five types of public notary documents as follows:

1) Notarial acts - documents on legal transactions and statements drawn up by public notaries,

2) Notarial minutes - minutes on the legal and other actions performed or witnessed by public notaries, 
3) Notarial certificates - certificates of facts witnessed by public notaries,

4) Notarial solemnization - non-public documents certified by public notaries, and

5) Notarial certifications - non-public documents relating to which a public notary certified a signature, or certified the authenticity of a transcript, translation or excerpt.

Depending on the type of the documents listed above, the participation of public notaries in drawing them up varies. Namely, a public notary performs notarial duties by independently taking procedural actions within its subjectmatter competence, or by acting on a judicial decision. By provision of article 98 of the Law on Public Notaries, the legislator stipulated a restriction to entrusting duties to a public notary, specifying by paragraph 3 of the same article that a court shall not entrust a public notary with the duties for which the court itself is competent according to the rules of the Law governing enforcement and security interest. Šarkić and Počuča (2012) disagree with this attitude of the legislator, invoking examples from comparative legislations, and considering this provision unreasonably rigid. In addition, this could make the impression of notary-public and enforcement law being totally disconnected as the legislator specified that public notaries may not be entrusted with duties regulated by enforcement and security procedures. Besides those listed above, we also have foreign public notary documents, which under the condition of mutuality have the same legal effect as the public notary documents drawn up according to the Serbian Law on Public Notaries. However, foreign public notary documents may not have legal effects in the Republic of Serbia which they do not have according to the law of the country in line with which they are issued (article 8, paragraphs 1 and 2 of the Law on Public Notaries, 2011).

\section{Public notary document as an enforceable document}

A public notary document has the effect of a public document only if issued in line with provisions of the Law on Public Notaries, i.e. if its drafting and issuance comply with all the essential conditions of form and legality stipulated by the law (article 7 of the Law on Public Notaries, 2011). The legislator's attitude is supported by Stanivuk and Šarkić (2018, p. 110), who think it is correct and that the requirement relating to the existence of particular elements should be precisely and strictly formulated, in such a way that without them a public notary document may not produce any legal effects. The aforesaid is also of special importance for the fact that a public document, 
among other things, serves as a proof of what is stated in it, while the probative force and presumption of truthfulness of a public document are generally refutable. Namely, it is allowed to prove that the facts in a public document were established in an incorrect way, or that the document was incorrectly drawn up (article 238, paragraph 3 of the Civil Procedure Law, 2011). On the other hand, Šarkić and Počuča (2012, p. 31) state that article 7 of the Law on Public Notaries does not correspond to reality, being totally contrary to the formal legality principle, which is applied in enforcement proceedings, with regard to enforceable documents which are enforced following the rules of enforcement proceedings. More precisely, the executive court, or enforcement officers $^{1}$ are in no way competent to review an enforceable document. And the legal provision referred to above, i.e. article 7, paragraph 1 of the Law on Public Notaries, implies that an executive court, or enforcement officer, would be empowered to review an enforceable document and suspend its enforcement if they establish that in the drawing up of a public notary document the conditions were not met which are required for a document to have the force of a public or enforceable document. In the opinion of the authors named above, this provision ought to be reconsidered given that the enforceability of a public notary document may not be refuted according to provisions of the Law on Enforcement and Security Interest. The public document property is relevant as an enforceable document is in fact a public document based on which enforcement may be requested (Šarkić \& Počuča, 2017). A public notary document is an enforceable or credible document when stipulated by the law (article 7, paragraph 2 of the Law on Public Notaries, 2011). Generally speaking, the legal system of the Republic of Serbia favoured the concept in which direct enforcement may be requested on the basis of the public notary documents which have the property of an enforceable document, which is additionally supported by provisions of the Law on Enforcement and Security Interest, which stipulates enforceable documents to be those public notary documents which, according to the law governing public notary issues, have the enforceable document property.

On the other hand Šarkić and Počuča $(2012$, p. 27) point out that not every document drawn up by a public notary is an enforceable document. Namely, public notaries draw up acts, minutes, perform solemnization, issue

\footnotetext{
1 It should be noted that in the Law on Enforcement and Security Interest of 2011 the legislator did not draw a terminological distinction between a professional enforcement officer and a court enforcement officer. As a result, the term public enforcement officer was introduced in the same Law in 2015 to emphasize that they carry out public authorities.
} 
certificates and perform certifications, and only the acts specified in a legally stipulated form, provided they meet the legally stipulated conditions, may be enforceable documents. Along the same lines Stanivuk and Šarkić (2018, p. 116) advocate the view that notarial certifications should be accepted as authentic documents based on which enforcement procedures could be instituted directly. They assume that the legislator wanted to assign the enforceable property to the public notary documents in which the public notary takes an active part, i.e. draws up the documents, pays attention to their contents, instructs the parties as to the legal consequences of statements, and in which they include the explicit statement of the debtor, that in case of their liability coming due, they agree to enforcement. A public notary document has the enforceability property if it specifies the debtor's obligations of acting, non-acting, giving and suffering, if the document identifies the creditor and the debtor, the enforcement subject, the scope and manner of enforcement, and the legal basis for issuing the public notary document, if it contains the debtor's consent to enforcement, or to the fact that this document has the enforceability property, as well as that the debtor's obligation has become due (Jakšić, 2006).

According to provision of article 41 paragraph 1, point $6^{2}$ of the Law on Enforcement and Security Interest (2015), a public notary document is a document admissible for instituting enforcement proceedings, i.e. adopting a writ of execution. By analyzing provisions of the Law on Enforcement and Security Interest, it becomes evident that according to the general rules of enforcement proceedings, the initiation of enforcement proceedings, or adopting a writ of execution is also possible in cases when we are dealing with certain public notary documents which would represent credible documents. In this way, this Law, for instance, stipulates that a credible document could include a certified document of a judgement debtor whereby they authorize a bank to transfer funds from their account to the judgement creditor's account. However, this document, or statement, is made in the form of a public notary document at a lower form level, which implies a public notary certification, and would be suitable for adopting a writ of execution. Yet, there are in theory certain doubts in this regard, with one opinion holding that this is not possible, and the opposite standpoint that this should be allowed as the parties can always resort to civil proceedings as an option to repeal the writ of execution in case when it was adopted on the basis of a credible document (Stanivuk \& Šarkić, 2018).

\footnotetext{
2 The article reads as follows: enforceable documents are the "public notary documents which have the force of an enforceable document".
} 
According to provision of article 85, paragraph 1 of the Law on Public Notaries, a notarial act is an enforceable document if it specifies a particular obligation of performance that the parties can agree on, and if it contains an explicit statement of the obligated individual that this document may, for the purpose of realization of any performance owed, be used after the obligation due date to directly implement enforcement proceedings. Furthermore, the legislator stipulated that if the court does not carry out the enforcement proceedings, the notarial act must also include other specific elements stipulated by law (article 85, paragraph 1 of the Law on Public Notaries, 2011).

By provision of article 82 of the Law on Public Notaries, the legislator stipulated that the form of notarial acts may be applied to contracts on the disposal of the immovable property of legally incapable persons, agreements on legal support, in line with the law, mortgage contracts and lien statements if they include the explicit statement by the obligated person that, based on the mortgage contract or the lien statement, with a view to realization of any performance owed, enforcement proceedings may be directly carried out following the obligation due date, by judicial or extrajudicial means. The law does not lay down the imperative form for those contracts, so that the parties are given a wide range of options for the enforcement of public notary documents which have the property of enforceability. In the drawing up of these documents, the role of the public notary is essential. Namely, it is their duty to investigate the lawfulness of the legal transaction, to point out any identified inadequacies to the parties, to propose alterations which would ensure a greater legal security and a better protection of their interests. Furthermore, they must establish if the parties have the legal and business capacity required for undertaking a specific legal activity, and if they are authorized to undertake it. In drawing up the document, the public notary is also under obligation to warn the debtor of the enforcement consequences and the risk of undergoing enforcement on the debtor's entire property. The public notary shall include all the warnings in the relevant document. In addition, the role of a public notary is not only reflected in concluding agreements between parties, but also in certifying the enforceability of the notarial act as such (Trgovčević Prokić \& Sibinović, 2016).

The notarial statement which has the enforceability property must include the debtor's consent. This consent, or statement by the debtor, must be explicit and unambiguous, in that the creditor may, following the obligation due date, carry out the direct enforcement proceedings. With that in mind, the public notary must ensure that such a statement by the debtor is made willingly and earnestly, because only then may it produce any legal effect. In addition, this statement implies that the issues in question are such that the 
parties may reach an agreement about them (Šarkić \& Počuča, 2017). There are no impediments to enforcing other kinds of debtors' statements and legal transactions in the form of notarial acts as well. It should be noted that in a notarial act the public notary will state the nature of the obligation that the parties agreed upon, as well as if the said obligation was fulfilled. On the basis of the parties' agreement with the aim of securing claims, a public notary may be the witness of establishing a mortgage on any real estate entered in the real estate register. A creditor may demand direct enforcement on the real estate in question upon the secured claim's coming due, if the debtor consented to that in the act (article 85, paragraph 3 of the Law on Public Notaries, 2011). In this way, a notarial act will contain a kind of security instruments, by means of which security may be achieved, the subject of the security instrument, the method of security instrument deletion from public records, subject to compliance with provisions of the law governing enforcement (Trgovčević Prokić \& Sibinović, 2016). It is naturally necessary to take into account the general rules of the Civil Procedure Law (2011) which is applied in enforcement proceedings, and in turn in the procedure of enforcement of public notary documents. To be precise, a provision of article 3, paragraph 3 of the Civil Procedure Law stipulates that a court shall not allow disposals by the parties which are inconsistent with enforcement regulations, the public order, rules of morality and good morals. Along the same lines court protection may not be requested by gamblers in order to collect a gambling debt, nor may an agreement be reached by which any parent waives their right to maintenance, nor a contract on the execution of a criminal act and the compensation for its commission (Šarkić \& Počuča, 2012).

\subsection{The due date for the enforcement of public notary documents}

A public notary is obliged to, in compliance with the free will of the parties, specify in the enforceable document the claim due date, so that a court or public enforcement officer may carry out the enforcement. Claim maturity may also be proved by certification of signatures on a private document or by solemnization, because the proving of claim maturity is subject to the legal requirement of presentation of a public or certified document. Solemnization is the verification of the contents of a private document. This term is employed in the Law on Extra-judicial Procedure (2015), while the Law on Public Notaries uses the term "certification of a non-public document", whereas other laws, such as the Law on Enforcement and Security Interest, employ the term "legally certified document". Trgovčević Prokić finds that this terminology is not 
acceptable as it does not distinguish the documents in terms of their probative value (Trgovčević Prokić, 2017, p. 112).

A public notary document becomes enforceable upon the expiry of the contractual period, on the expiry of the last day agreed upon to fulfil the claim. For enforcement purposes, the public notary will, in the copy of the original document, emphasize that the period for fulfilment of the claim has expired. They shall also state the final claim fulfilment date, as well as the fact that the document has thus become enforceable. If a public notary document does not include the claim due date, it would be unacceptable for direct enforcement. If the claim due date may not be determined, i.e. the enforceable document does not specify the term for the willing fulfilment of commitments, it shall amount to eight days as of the day of delivery of the enforceable document to the judgement debtor (article 47, paragraph 1 of the Law on Enforcement and Security Interest, 2015). When conditions for voluntary compliance are met, according to the Law on Enforcement and Security Interest, the voluntary compliance period, usually lasting 15 days, begins, provided that it can be both longer or shorter if so defined by a judicial decision. If no period is stipulated by the judicial decision, enforceability shall take effect upon expiry of the 15-day period. In that regard, it is necessary to draw a distinction between enforcement and enforceability as a possibility for enforcement in terms of acceptability with regard to the condemnatory force of an enforceable document to be suitable to be enforced in line with the general rules of the Law on Enforcement Proceedings (Šarkić \& Počuča, 2012). However, given that the public notary does not here attest to a verdict, but an agreement between parties, the non-existence of a specified due date prevents the realization of enforcement. As a result, this kind of notarial act may not be acceptable for enforcement and it does not have the effect of an enforceable document (Trgovčević Prokić \& Sibinović, 2016). In addition, the maturity of a claim may also be determined in a corresponding civil procedure, by delivering a verdict or reaching a settlement. However, this form of settlement does not represent a desirable solution for the creditor, as the parties practically go back to the civil procedure which they wanted to avoid in the first place (Stanivuk \& Šarkić, 2018).

\subsection{The enforcement of a foreign public notary document}

With regard to foreign public notary documents, which are directly enforceable by a foreign law, they are also directly enforceable in the Republic of Serbia if they refer to rights which are not inconsistent with the Republic of Serbia legal system, and if they contain all the elements required for enforcement by the Republic of Serbia law (article 8, paragraph 4 of the Law on Public 
Notaries, 2011). It follows from the aforesaid that a notarial act which in the country of origin has the force of an enforceable document is treated in the same way in the Republic of Serbia. However, the basis for that is also the existence of all the elements stipulated by the Republic of Serbia legislation, which are essential for enforcement. This means that the legislator stipulates restrictions with regard to whether a notarial act is an enforceable document in the country of origin. It is therefore necessary for the court or enforcement officer who is to enforce the foreign public notary document, to be exceptionally knowledgeable about the regulations of the country in question, to be able to determine if it is an enforceable document. In doing so they must take into account the different legal organizations of the respective countries, any terminological confusions, and any structural issues as well (Šarkić, 2010; Živković, 2007). It could happen in certain cases, for instance, that the same notarial act was drawn up by both a domestic and a foreign public notary. In these situations the notarial act is deemed a domestic public document if certified by the seal and stamp of a domestic public notary. In any case this is in the parties' interest, so that this legal provision will positively affect the legal transactions. The aforesaid situation may occur in case of mixed marriages, or if there is a legal transaction taking place between a local and a foreign citizen (Šarkić \& Počuča, 2012).

\section{Conclusion}

The introduction of the public notary document as an enforceable document is a very useful and positive innovation in the Republic of Serbia legislation. Namely, the possibility of instituting enforcement proceedings on the basis of public notary documents which have the enforceable capacity without previously conducting any administrative or court proceedings before other government authorities represents a benefit for private interests, or interests of the parties. Particular protection is thus provided for creditors, who can, based on public notary documents, demand enforcement to be carried out. There is a certain relief for the debtor as well, who will not be under obligation to pay the expenses of civil procedure. Furthermore, this kind of documents significantly relieves the courts and administrative authorities of certain activities, saves resources and is very efficient as well. A characteristic of public notary documents with enforceable effect is that their drawing up and contents must be strictly complied with, because if a public notary document is not drawn up in the specified form, it may not produce legal effect. In drawing up a public notary document, the public notary must pay attention to all its elements, the interests of the parties, and 
the validity of the legal transaction. They must also accurately define the security instrument types, the methods of security realization in case of enforcement, as well as the security instrument object. On the other hand, the legislator also stipulated a restriction to entrusting duties to public notaries, being duties within the competence of the court, so that it is our opinion that public notaries, in view of the fact they perform their activities as impartial commissioners of the parties, guaranteeing the security of legal transactions, should also be assigned a role in enforcement proceedings.

\section{Krstinić Dalibor}

Doktor pravnih nauka, Docent, Pravni fakultet za privredu i pravosuđe, Univerzitet Privredna akademija u Novom Sadu, Srbija

\section{Zarubica Sara}

Magistar pravnih nauka, Doktorand na Pravnom fakultetu, Univerzitet u Beogradu, Srbija

\section{IZVRŠENJE JAVNOBELEŽNIČKIH ISPRAVA}

REZIME: Donošenjem Zakona o javnim beležnicima srpski zakonodavac uređuje pitanje poslovanja javnih beležnika, njihovih usluga i poslova. Savremena javnobeležnička delatnost predstavlja specifičnu pravnu delatnost koja doprinosi povećanju pravne sigurnosti, rasterećenju sudova, što utiče i na efikasnije ostvarivanje prava građana, koji mogu lakše i brže da realizuju svoja građanska prava. Javni beležnik obavlja samostalno i nezavisno javnu službu i pri tome je i nezavisni poverenik stranke, a njegovo učešće prilikom sastavljanja isprava potvrđuje njihovu istinitost i sadržaj. Stoga javnobeležničke isprave zauzimaju relevantno mesto u savremenom pravnom prometu. Javnobeležničke isprave prema Zakonu o javnom beležništvu imaju svojstvo izvršnosti, pod određenim uslovima i na njihovoj bazi se može neposredno pokrenuti postupak izvršenja pred sudom kada za to postoje predviđeni uslovi, koji se smatra pozitivnim i veoma korisnim zakonskim rešenjem, zbog čega će u okviru rada autori ukazati na neke relevantne odrednice i specifičnosti koje se odnose na izvršenje javnobeležničkih isprava.

Ključne reči: javni beležnik, javnobeležnička isprava, javnobeležničiki zapis, izvršna isprava 


\section{References}

1. Gelevski, S. \& Golić, D. (2008). Javni beležnik - notar [Public Notary]. Pravo - teorija i praksa, 25 (3-4), pp. 20-30

2. Jakšić, A. (2005). Notarijat kao javna služba [Notary Service as a Public Service]. In: Hiber, D. (ured.), Javnobeležničko pravo [Public Notary Law] (pp. 85-106). Beograd: Centar za publikacije Pravnog fakulteta Univerziteta u Beogradu

3. Jakšić, A. (2006). Izvršnost notarijalne isprave [The Enforceability of a Notarial Document]. In: Hiber, D. (ured.), Javnobeležničko pravo [Public Notary Law] (pp. 169-178). Beograd: Pravni fakultet

4. Stanivuk, B. \& Šarkić, I. (2018). O izvršnosti javnobeležničkih isprava u Republici Srbiji [On the Enforceability of Public Notary Documents in the Republic of Serbia]. In: Šarkić, N. et al. (prir.), Četrdeset godina izvršnog zakonodavstva u građanskim postupcima: zbornik radova [Forty Years of Enforcement Legislation in Civil Procedures: proceedings] (pp. 107-123). Beograd: Pravni fakultet Univerziteta Union i Službeni glasnik

5. Trgovčević Prokić, M. (2007). Ovlašćenja javnog beležnika [Public Notary Authorities]. Beograd: Službeni glasnik

6. Trgovčević Prokić, M. (2016). Izvršna javnobeležnička isprava i sredstva obezbeđenja [The Enforceable Public Notary Document and Security Instruments]. Evropsko zakonodavstvo, 15 (55), pp. 124-157

7. Trgovčević Prokić, M. (2017). Javnobeležnički zapis i solemnizacija [Notarial Act and Solemnization]. Pravni život, 66 (12), pp. 101-115

8. Trgovčević Prokić, M. \& Šarkić, N. (2013). Priručnik sa komentarom Zakona o javnom beležništvu, prilozima i obrascima [An Annotated Manual of the Law on Public Notaries, with appendices and forms]. Beograd: Paragraf Co i Novi Sad: Paragraf Lex

9. Trgovčević Prokić, M. \& Sibinović, Đ. (2016). Izvršna javnobeležnička isprava [Enforceable Public Notary Document]. In: Šarkić, N., (red.), Primena novog Zakona o izvršenju i obezbeđenju: zbornik radova [The Implementation of the New Law on Enforcement and Security Interest: proceedings] (pp. 289-345). Beograd: Glosarijum

10. Šarkić, N. (2004). O javnom beležniku - notaru [On the Public Notary]. Beograd: Glosarijum

11. Šarkić, N. (2010). Priznanje i izvršavanje stranih izvršnih i javnobeležničkih (notarskih) isprava [The Recognition and Enforcement of Foreign Enforceable and Public Notary Documents]. Pravni informator, 13 (12), pp. $1-23$ 
12. Šarkić, N. \& Počuča, M. (2012). Izvršno i javno beležničko (notarsko) pravo, [Enforcement and Public Notary (Notarial) Law]. Pravni život, 61 (12), pp. 23-43

13. Šarkić, N. \& Počuča, M. (2017). Izvršenje javnobeležničkih akata prema odredbama novog Zakona o izvršenju i obezbeđenju [The Enforcement of Notarial Acts according to Provisions of the New Law on Enforcement and Security Interest]. Pravni život, 66 (12), pp. 83-99

14. Šarkić, N., Radulović, D. \& Počuča M. (2018). Posebni građanski postupci [Special Civil Procedures]. Beograd: Pravni fakultet Univerziteta Union i Službeni glasnik

15. Živković, M. (2007). Izvršenje stranih odluka (stranih izvršnih isprava) u pravu Srbije [The Enforcement of Foreign Decisions (Foreign Enforceable Documents) in Serbia Law]. Evropski pravnik, 2 (1), pp. 103-109.

16. Živković, M. \& Živković, V. (2013). O uvođenju javnog beležništva u Srbiji [On the Introduction of Public Notaries in Serbia]. Zbornik Pravnog fakulteta u Zagrebu, 63 (2), pp. 433-448

17. Zakon o izvršenju i obezbeđenju [The Law on Enforcement and Security Interest]. Sl. glasnik $R S$, no. 106/15, 106/16 - authentic interpretation, $113 / 17$ - authentic interpretation and 54/19

18. Zakon o javnim beležnicima Kraljevine Jugoslavije [The Law on Public Notaries of the Kingdom of Yugoslavia]. Službene novine, no. 220/30

19. Zakon o javnom beležništvu [The Law on Public Notaries]. Službeni glasnik $R S$, no. 31/11, 85/12, 19/13, 55/14 - other law, 93/14 - other law, $121 / 14,6 / 15$ i $106 / 15$

20. Zakon o opštem upravnom postupku [The Law on General Administrative Procedure]. Službeni glasnik RS, no. 18/16i 95/18-authentic interpretation

21. Zakon o parničnom postupku [The Civil Procedure Law]. Službeni glasnik $R S$, no. 72/11, 49/13, 74/13, 55/14, 87/18 and 18/20

22. Zakon o vanparničnom postupku [The Law on Extra-Judicial Procedure]. Službeni glasnik SRS, no. 25/82 and 48/88 and Službeni glasnik $R S$, no. 46/95 - other law, 18/05 - other law, 85/12, 45/13 - other law, 55/14, 6/15 and 106/15 - other law 